九州大学学術情報リポジトリ

Kyushu University Institutional Repository

\title{
DESCRIPTIONS FEMALE OF TWO NEW SPECIES AND ONE UNRECORDED OF THE GENUS ANDRENA FROM JAPAN (HYMENOPTERA, ANDRENIDAE)
}

Tadauchi, 0samu

Hirashima, Yoshihiro

https://doi.org/10.5109/2495

出版情報: ESAKIA. 25，pp.133-139，1987-01-31. Entomological Laboratory，Faculty of Agriculture, Kyushu University

バージョン：

権利関係 : 


\title{
DESCRIPTIONS OF TWO NEW SPECIES AND ONE UNRECORDED FEMALE OF THE GENUS ANDRENA FROM JAPAN (HYMENOPTERA, ANDRENIDAE) $^{1,2)}$
}

\author{
Osamu Tadauchi and Yoshiniro Hirashima \\ Entomological Laboratory, Faculty of Agriculture, \\ Kyushu University, Fukuoka 812, Japan
}

\begin{abstract}
Two new species of the genus Andrena, A. (Euandrena) taisetsusana, and A. (Melandrena) anzu, are described from Japan. The female of A. (Hoplandrena) macroceps (Matsumura) is described for the first time.
\end{abstract}

Recently we revised some Japanese subgenera of the genus Andrena primarily based on the material collected by Tadauchi (Tadauchi, 1985 ; Tadauchi and Hirashima, 1983, 1984a, 1984b ; Tadauchi, Hirashima and Matsumura, 1987). In this paper we describe two new species and the female of Andrena (Hoplandrena) macroceps (Matsumura) which has been known for a long time by the holotype male only. Presently the Japanese Andrena is composed of 78 species in all. The check list with some synonymies and the key will be published in separate papers (Tadauchi and Hirashima, in preparation).

We are grateful to Assoc. Prof. Y. Maeta of Shimane Univ., Mr. T. Matsumura of Nat. Grassland Res. Inst., Mr. M. Usui of Alberta, Canada, Assoc. Prof. H. Fukuda of Hokkaido Univ., Mr. I. Takahashi (through Prof. M. Munakata) of Hokkaido, Prof. T. Saigusa of Kyushu Univ., Dr. K. Baba of Niigata Pref., and Dr. K. Kamijo of Hokkaido Forest Exp. Station for their gift or loan of valuable specimens. Tadauchi is also indebted to Prof. S. F. Sakagami of Hokkaido Univ. for his kind help and suggestions in his stay in Hokkaido and to Assoc. Prof. S. Inoue of Kyushu Univ. Forests, Ashoro, Hokkaido, for identification of some plants.

\section{Andrena (Euandrena) taisetsusana, new species}

This is a unique species in our fauna. It is somewhat similar to Andrena (Euandrena) tateyamana Tamasawa et Hirashima. But it can be separable from tateyamana by the process of labrum smaller and semicircular, the facial fovea brighter, the head and thorax with pale yellowish to yellowish hairs not mixed with blackish, and the 1 st metasomal tergum nearly smooth and shiny with sparse punctures. It occurs in Mts. Taisetsu, Hokkaido and northern Honshu (Niigata Pref.). This species has been collected mainly on the flowers of Salix and Taraxacum.

1) Partly supported by a grant (1984) from the Japan Society for the Promotion of Science, Tokyo.

2) Contribution from the Entomological Laboratory, Faculty of Agriculture, Kyushu University, Fukuoka (Ser. 3, No. 222). 
Female : Length $11.0-12.0 \mathrm{~mm}$.

Integumentalcolor: Flagellar segments beneath brownish; hind tibiae and tarsi brownish ; posterior margins of metasomal terga yellowish brown subhyaline.

Pubescence : Hairs on head and thorax pale yellowish to yellowish above, whitish below, not long, dense ; those on clypeus scanty ; those on antennal region and vertex mixed with pale brownish ; facial fovea pale brownish above, whitish below ; facial fovea with upper end occupying $2 / 3$ of space between eye and post ocellus ; propodeal corbicula well developed with dorsal fringe of long, dense, more or less well curled hairs ; interior of propodeal corbicula with coarse, simple hairs ; trochanteral floccus well developed, long, well curled, whitish ; femoral floccus white ; tibial scopa composed of somewhat loose, whitish hairs all over or very narrowly pale brownish behind ; hairs on metasomal terga scanty, white, tergum 1 long, erect, terga 2-5 short, erect to suberect; posterior margins of metasomal terga 2-4 with lateral fringes of dense, appressed, white hairs; caudal fimbria brown.

Structure : Process of labrum small, semicircular ; malar space about $1 / 5$ times as long as base of mandible ; clypeus well convex, weakly tessellate and weakly punctate all over, without a median longitudinal, impunctate space; flagellar segment 1 twice as long as 2 , which is as long as 3 ; pronotum with lateral suture indicated below, short, without humeral ridge; mesoscutum weakly tessellate with shallow punctures ; dorsal face of propodeum shagreened ; enclosure ill defined, rugose on basal $2 / 3$, tessellate apically ; mesepisternum shagreened anteriorly, densely tessellate with indistinct, shallow punctures posteriorly ; metasomal tergum 1 nearly smooth and shiny with sparse, fine punctures, terga 2-5 weakly tessellate with sparse, indistinct, fine punctures; posterior depressions of terga occupied apical $1 / 3$ of terga, well indicated ; pygidial plate with a raised, large, triangular area in the middle.

M ale : Length $9.0-10.0 \mathrm{~mm}$.

Integumental color : Mandibles reddened apically ; flagellar segments beneath brownish ; posterior margins of metasomal terga reddish brown subhyaline.

Pubescence : Hairs on head and thorax not long, dense, dull whitish to pale yellowish above, whitish below, not mixed with brownish or blackish ones; those on mesoscutellum long, dense, pale yellowish ; those on legs whitish except for tarsi, which are pale yellowish ; those on metasomal terga scanty, whitish, tergum 1 long, erect, terga 2-6 short, erect to suberect; posterior margins of metasomal terga 2-4 with lateral fringes of not dense, white hairs.

Structure : Malar space short, about $1 / 6$ times as long as base of mandible ; process of labrum transverse ; clypeus nearly smooth to very weakly tessellate and shiny with dense, strong punctures, without or with a narrow, median, longitudinal, impunctate space; flagellar segment 1 about 1.3 times as long as 2, which is slightly shorter than 3 ; mesoscutum and mesoscutellum moderately tessellate with sparse, indistinct punctures ; dorsal face of propodeum shagreened ; enclosure of propodeum ill defined, rugose on basal half, tessellate on apical half; mesepistemum shagreened anteriorly, tessellate with shallow punctures posteriorly ; metasomal terga weakly tessellate, with sparse, indistinct, fine punctures ; posterior depressions of terga well indicated, occupied $1 / 3$ of terga ; genitalia and associated structures as illustrated (Figs. 1-5).

Distribution : Japan (Hokkaido and northern Honshu). (Fig. 6)

F LORAL RECORDS : 77 females and 2 males were collected on 5 plants. Salicaceae :Salix taraikensis Kimura (55910). Compositae : Taraxacum officinale Weber (309); Petasites japonicus subsp. giganteus Kitam. (10) ; Barbarea vulgaris R. Br. (19); Chrysanthemum leucanthemum Linn. (19).

Fitght RECoRds : Females have been taken from mid May to late June, and males in mid May in Mts. Taisetsu, Hokkaido. One female was collected in mid May in Niigata Pref., northern Honshu. Type material : Holotype female (Type No. 2585, Kyushu Univ.), Tokachimitsumata, Mts. Taisetsu, Hokkaido, 29. v. 1984 (0. Tadauchi). Paratypes :82 $110^{7}$, same data as holotype. 

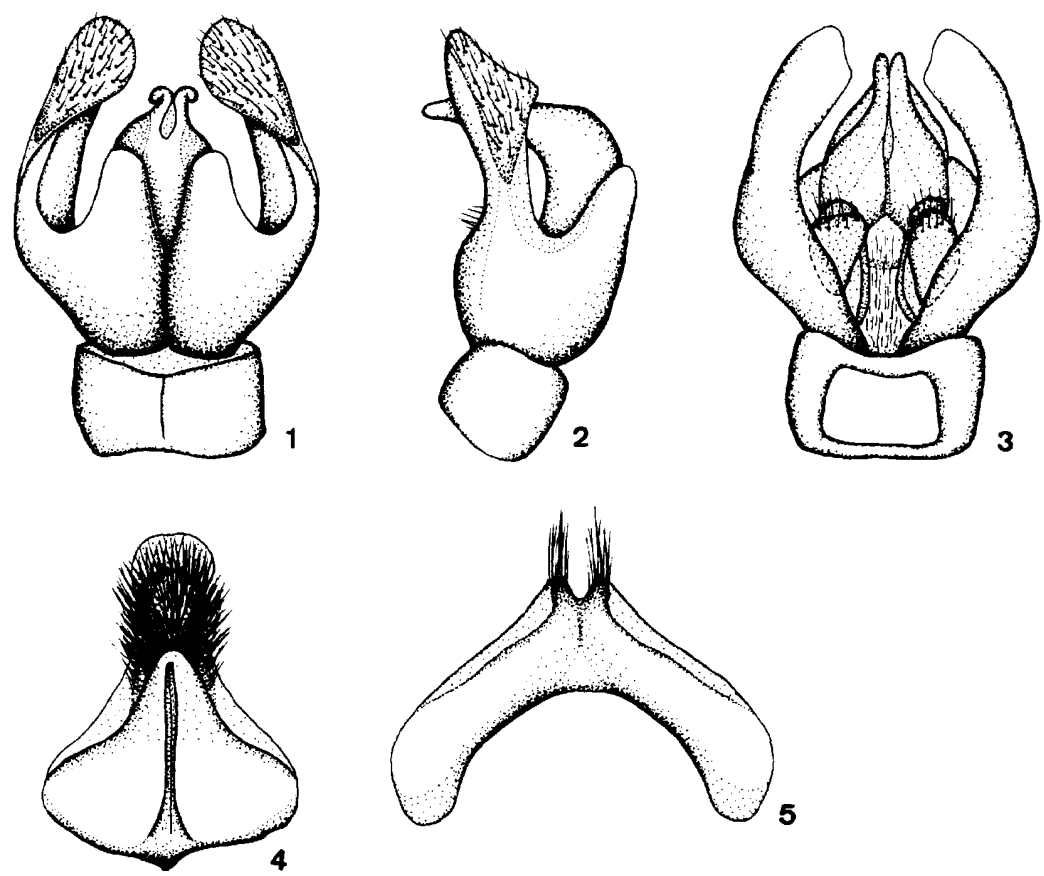

Figs. 1-5. Genital capsule and associated structures of Andrena(Euandrena) taisetsusana, n. sp., 1 : dorsal view of genital capsule, 2 : lateral view of the same, $3:$ ventral view of the same, $4: 7$ th sternum, $5: 8$ th sternum.

SPectmens examined other than the types : HOKKAIDO : same locality as holotype :19,12. vi. 1984 (0. Tadauchi), 1, 30. vi. 1984 (0. Tadauchi) ;1 ;, Horoka, Tokachi, 1. vi. 1976 (M. Usui) ;1 $\$ 2 \sigma^{\prime}$, Nukabira-Yamada Spa, 16. v. 1976 (T. Matsumura) ;107, Yamada Spa, Tokachi, 16. v. 1976 (M. Usui) ;2\%, Obako, Taisetsu, 18. vi. 1974 (H. Fukuda). HONSHU :1\%, Kurokawa, Niigata Pref., 18. v. 1980 (K. Baba).

The specific name is derived from the type locality, Mts. Taisetsusan, Hokkaido.

\section{Andrena(Melandrena) anzu, new species}

This new species is somewhat similar to Andrena(Gymnandrena)edashigei Hirashima. But the recognition of it is easy owing to the following characters: the posterior margins of the metasomal terga 3-5 with pale brownish, obscure, suberect hair bands ; the tibia1 scopa small, composed of short, pale brownish hairs, narrowly plumose both in front and behind; the clypeus less convex and tessellate all over with sparse, shallow punctures; the clypeus broader than long ; the thorax with dense, fulvous hairs not mixed with brownish ones ; and the process of labrum slightly emarginate in the middle.

This species was collected in late April in Nagano Pref., central Honshu by Dr. Y. Maeta. It was taken on the flower of Prunus armeniaca L.

Female: Length $11.0 \mathrm{~mm}$.

Integumental color: Flagellar segments beneath brown ; posterior margins of metasomal terga brownish subhyaline. 


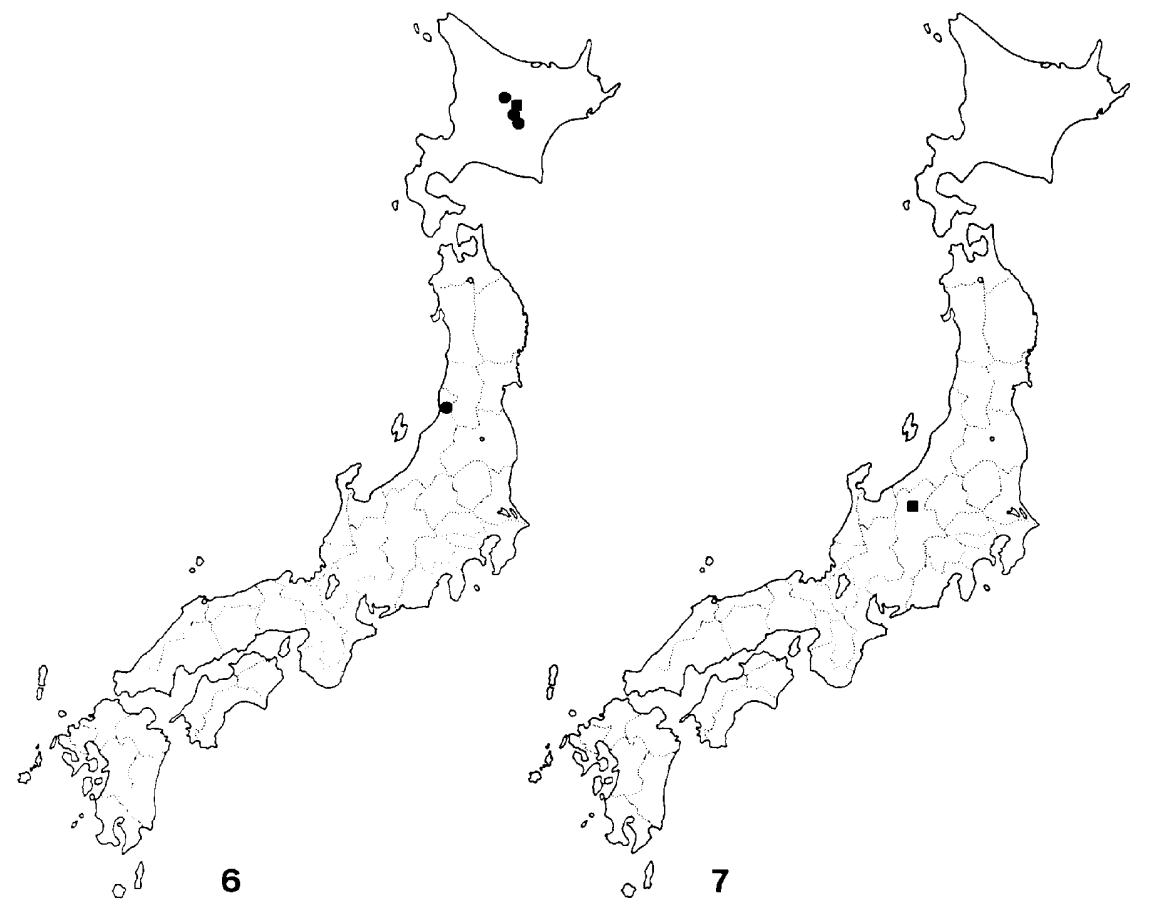

Figs. 6-7. Maps showing the distribution of Andrena(Euandrena) taisetsusana, n. sp. (6) and Andrena (Melandrena) anzu, n. sp. (7).

Pubescence : Hairs on head short, dense, fulvous ; those on paraocular area near eye and vertex brownish ; facial fovea brown above, paler below, with upper end occupying $3 / 4$ space between eye and post ocellus; hairs on thorax dense, fulvous above, paler below, not mixed with brownish or blackish ones; propodeal corbicula perfectly developed with well curled, long, dense hairs dorsally and anteriorly ; trochanteral floccus and femoral floccus fulvous ; tibial scopa small, composed of short, pale brownish hairs, narrowly plumose both in front and behind; hairs on metasomal terga scanty, fulvous, tergum 1 long, erect to suberect, terga 2-5 short, suberect; posterior margins of metasomal terga 3-5 with pale brownish, obscure, suberect hair bands, bands of 4 and 5 complete ; caudal fimbria brown.

Structure : Process of labrum transverse, slightly emarginate apically; malar space linear ; clypeus broader than long, not well convex, weakly tessellate all over with small, weak punctures ; clypeus with a narrow, median, longitudinal, impunctate space; pronotum with lateral suture indicated below, short, without humeral ridge ; mesoscutum densely tessellate with dense, more or less roughened punctures anteriorly and laterally, and smooth and shiny with medium sized, strong, sparser punctures in the middle; mesoscutellum smooth and shiny with smaller, denser punctures anteriorly and larger, sparser ones posteriorly ; dorsal face of propodeum roughened, dull ; enclosure ill defined, rugose on basal half, tessellate on apical half ; mesepistemum roughened, narrowly and densely tessellate posteriorly ; metasomal terga smooth and shiny, tergum 1 with small, sparse punctures, terga 2-4 with denser punctures; posterior depressions of metasomal terga not well indicated.

Distribution : Japan (central Honshu). (Fig. 7) 
Floral RECORD : Rosaceae : Prunus armeniaca L. (19).

FLIGHT RECORD : Female : late April.

Type MAterlal: Holotype female (Type No. 2586, Kyushu Univ.), Mori, Koshoku, Nagano Pref., 21-22. iv. 1963 (Y, Maeta).

The specific name is derived from Japanese name of the visiting flower, Prunus armeniaca L.

\section{Andrena (H oplandrena) macroceps (Matsumura)}

Melitta macroceps Matsumura, 1912, Thous. Ins. Japan, Suppl. 4 : 207, male.

Andrena (Hoplandrena) macroceps Hirashima, 1964, J. Fac. Agr., Kyushu Univ., 13 : 96, male (redescription) ; Hirashima, 1966, J. Fac. Agr., Kyushu Univ., 14 : 115 (in key) ; Tadauchi and Hirashima, 1984, Kontyâ, $52: 285$ (in key).

This species was described based on a holotype male only by Dr. Matsumura from Sapporo, Hokkaido. It has been unknown for a long time after the description of this species. In the present study we could examine 8 females and 35 males of this species mainly collected on Mts. Taisetsu, Hokkaido. The female of this species is very close to Andrena (Hoplandrena) pruniphora Hirashima and somewhat similar to the European Andrena carantonica Pérez. But the first generation of it can be separable from that of pruniphora by the process of labrum not emarginate in the middle, the hairs on the thorax shorter and paler, the tibial scopa dull whitish nearly all over or very narrowly pale brownish behind, and the male clypeus and vertex without dark brown hairs. It is also separated from carantonica by the head without black hairs, the metasomal terga scanty of hairs with dense, white hair bands on the terga 2-4.

Hirashima (1964) remarked that no one can determine whether this species flies in May or August because the collecting date of it was shown as 5/8. However, we now judge that the holotype of macroceps was taken on the 8 th of May, because it shows a feature of the first generation of Hoplandrena, i. e., the presence of the spine on the malar space and the modification of the mandibles, which were shown by our study (Tadauchi and Hirashima, 1984). Tadauchi also noticed that Dr. Matsumura used to write A/B (A : month, B : day) for his data, judging from his collection preserved in the Entomological Laboratory, Hokkaido University.

The description of female, which is new to science is given below.

Female : Length 12.0-14.0 mm.

In tegumen tal color: Flagellar segments beneath reddish brown; metasomal terga yellowish brown subhyaline apically.

Pubescence : Hairs on head and thorax fulvous ; those on clypeus rather sparse, short, those on vertex not mixed with brownish or blackish ones ; facial fovea chocolate above, yellowish below ; facial fovea with upper end occupying nearly full space between eye and post ocellus; hairs on mesoscutum fulvous, short, those on mesoscutellum longer ; propodeal corbicula with dorsal fringes of dense, not specially well arranged, fulvous hairs ; interior of corbicula with coarse, simple hairs ; tibial scopa compact, composed of moderately long, coarse, simple, dull whitish hairs nearly all over or narrowly pale brownish behind; metasomal terga scanty of hairs, tergum 1 with long, erect, fulvous hairs ; terga 3-5 with very short, sparse, suberect, fuscous hairs ; apical margin of metasomal terga 2-4 with dense, appressed, white hair bands, band of 3 slightly interrupted in the middle, and that of 4 complete ; caudal fimbria brown.

Structure: Process of labrum flat, transverse, more than twice as broad as long, with apical margin entire; malar space about $1 / 4$ times as long as base of mandible ; clypeus well convex, tessellate on basal $1 / 5$, very weakly tessellate to nearly smooth apically with medium sized, close, more or less roughened punctures ; clypeus with an indication of median, longitudinal, impunctate 

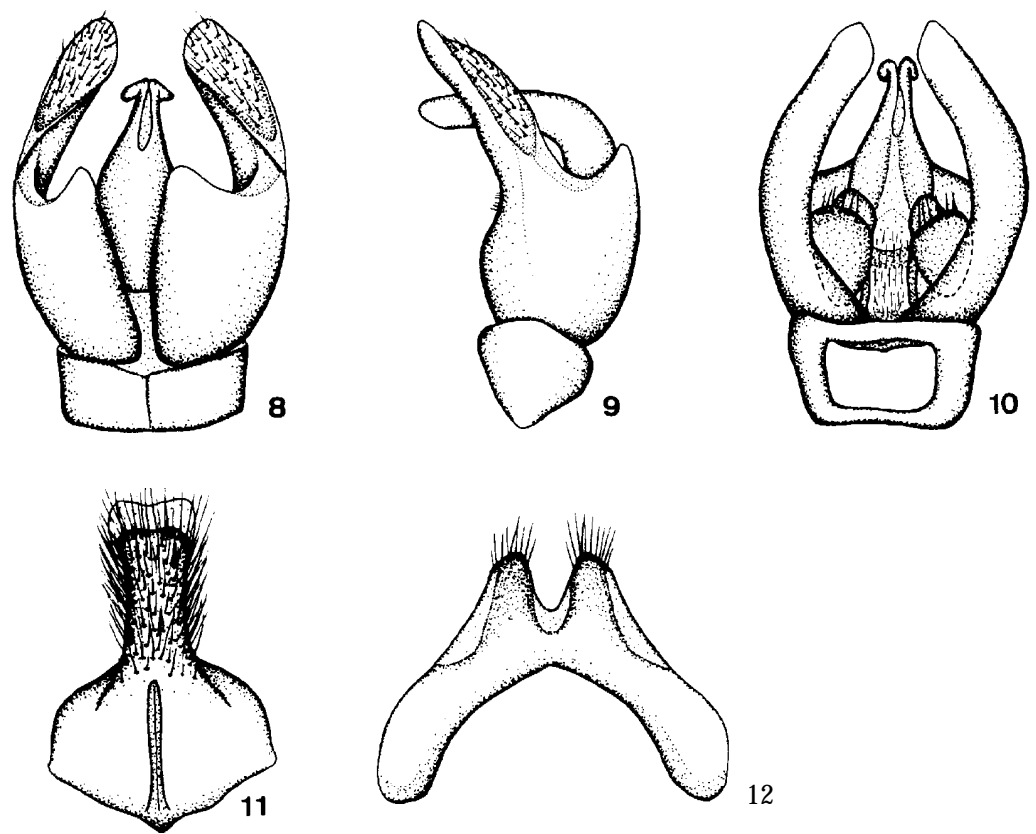

Figs. 8-12. Genital capsule and associated structures of Andrena(Hoplandrena) macroceps (Matsumura), $8:$ dorsal view of genital capsule, $9:$ lateral view of the same, $10:$ ventral view of the same, 11: 7 th sternum, $12: 8$ th sternum.

space ; eyes with inner margins subparallel sided ; flagellar segment 1 shorter than 2 plus 3,2 slightly shorter than 3 ; pronotum weakly tessellate with sparse, shallow punctures ; pronotum with lateral suture indicated below, short, without humeral ridge; apical transverse groove of pronotum not notched in the middle; mesoscutum weakly tessellate with small, sparse, shallow punctures ; propodeal enclosure ill defined, rugose on basal half and tessellate on apical half ; dorsal face of propodeum shagreened ; mesepisternum shagreened anteriorly, densely tessellate with shallow punctures posteriorly; metasomal terga densely tessellate, tergum 1 with small, indistinct punctures ; apical depressions of metasomal terga narrow, very weak.

\section{Male :}

Structure: Genitalia and associated structures are firstly figured (Figs. 8-12).

DistRibution : Japan (Hokkaido). (Fig. 13)

FLORAL RECORDS : 5 females and 35 males were collected on 4 plants. Salicaceae : Salix taraikensis Kitamura (2\$350'). Rosaceae : Rubus crataegifolius Bunge (19). Cruciferae : Cardamine leucantha o. E. Schulz (19). Leguminosae :Trifolium repens L. (19).

Fught Records : Female : late May to early July. Male : early May to late May.

Specimens EXAMINED : HOKKAIDO :2\$350 , Tokachimitsumata, Mts. Taisetsu, 29. v. 1984 (0. Tadauchi) ;19, Mt. Rausu, Shiretoko, 23. vi. 1963 (T. Saigusa) ; 19, Aizankei, Mts. Taisetsu, 3. viii. 1957 (K. Kamijo) ; 29, Hakodateyama, Hakodate, 7. vi. 1961 (I. Takahashi) ; 19, same locality and collector as above, 14. vi. 1961.

\section{R eferences}

H irashima, Y., 1964. Systematic and biological studies of the family Andrenidae of Japan 


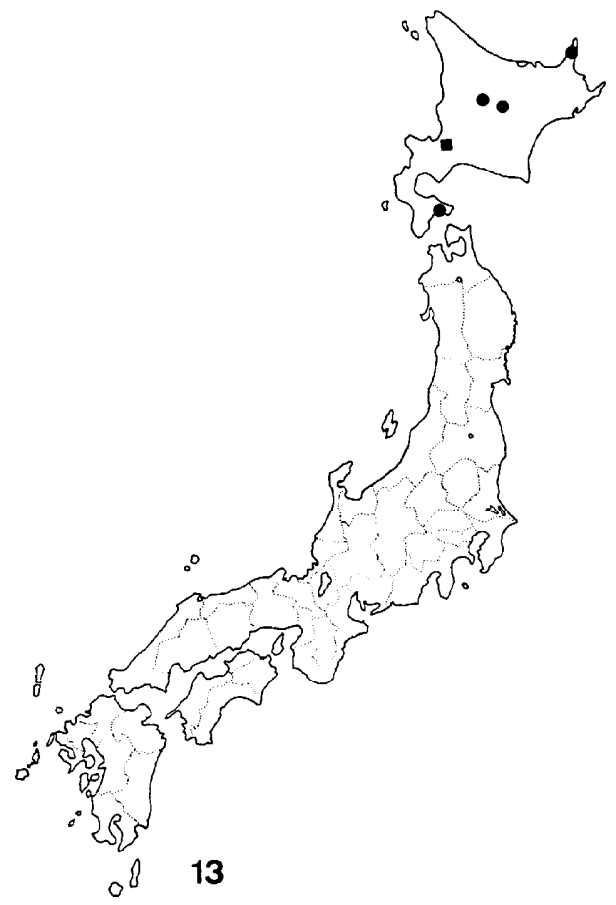

Fig. 13. Map showing the distribution of Andrena(Hoplandrena)macroceps (Matsumura). A square indicates the type locality.

(Hymenoptera, Apoidea). Part 2. Systematics, 4. J.Fac. Agr., Kyushu Univ., 13 : $71-97$.

—, 1966. Ditto. Part 2. Systematics, 7. Ibid., 14: 89-131.

LaBerge, W. E., 1986. A revision of the bees of the genus Andrena of the western Hemisphere. Part

XI. Minor subgenera and subgeneric key. Trans. Amer. Ent. Soc., 111: 441-507.

Matsumura, S., 1912. Thousand Insects of Japan, Supplement IV. 247 pp. Keiseisha, Tokyo. (in Japanese with English summary)

Osytshnjuk, A.Z., 1986. New palaearctic species of the subgenus Euandrena Hed. (Hymenoptera,

Andrenidae, Genus Andrena F.). Rev. Entomol. URSS, 65 : 407-418.

Schmiedeknecht, O., 1930. Die Hymenopteren nord- und mitteleuropas. Zweite Auflage. 1062 pp.

Tadauchi, O., $\quad$ 1985. Synopsis of Andrena(Micrandrena) of Japan (Hymenoptera, Andrenidae) Parts

I \& II. J.Fac. Agr., Kyushu Univ., 30 : 59-76, 77-94.

-and Y. Hirashima, 1983. New or little known bees of Japan (Hymenoptera, Apoidea) IV.

Supplements to Andrena (Simandrena). Esakia, (20) : 81-92.

— and —, 1984a. Ditto. V. Supplements to Andrena (Hoplandrena). Kontyâ, 52 : 278-285.

— and —-, 1984b. Synopsis of Andrena(Euandrena) of Japan (Hymenoptera, Andrenidae).

Esakia, (22) :107-113. and T. Matsumura, 1987. Synopsis of Andrena (Andrena) of Japan (Hymenoptera,

Andrenidae) Parts I \& II. J. Fac.Agr., Kyushu Univ., 31 : (in press).

Warncke, K., 1968. Die Untergattungen der westpalaarktischen Bienengattung Andrena F. M em.

Est. Mus. Zool. Univ. Coimbra, (307) : 5-111. 